\title{
REPRESENTATION OF AFRICAN AMERICAN IN GHOSTBUSTERS (2016) MOVIE
}

\author{
Lentera Paramuswari ${ }^{1 *}$, Fanny Lesmana ${ }^{1}$, Daniel Budiana $^{1}$, \\ ${ }^{1}$ Department of Communication Sciences, Petra Christian University Surabaya \\ *Corresponding author; Email: lentera95@gmail.com
}

\begin{abstract}
Discrimination towards African American ethnic is a long drawn issue in America. Leslie Jones, an African American actress, received racist tweets after played a role in Ghostbusters (2016) movies. Ghostbusters (2016) is a film that tells the struggle of a group of scientists and an African American to prove the existence of ghost scientifically. This descriptive qualitative study aims to find out how are the Representation of African American in the Ghostbusters (2016) movie by using semiotic method John Fiske. The results of this study show that the character of African Americans in Ghostbusters (2016) movie is still described as being under the white social class both economically and intelligently. Moreover, Ghostbusters (2016) use African American stereotype characteristics as their comical content. Last, African American role in Ghostbusters (2016) was only as white sidekicks.
\end{abstract}

Keywords: Representation, African American, movie, semiotics, Ghostbusters the movie 2016.

\begin{abstract}
ABSTRAK
Diskriminasi terhadap etnis Afrika America merupakan isu yang berkepanjangan di Amerika. Leslie Jones, seorang aktris Afrika Amerika menerima banyak tweets berbau rasisme setelah memerankan sebuah karakter dalam film Ghostbusters (2016). Ghostbusters (2016) merupakan film yang menceritakan perjuangan sekelompok ilmuwan dan seorang Afrika Amerika untuk membuktikan keberadaan hantu secara ilmiah. Penelitian deskriptif kualitatif ini bertujuan untuk mencari tahu bagaimana penggambaran orang Afrika Amerika dalam film Ghostbusters (2016) dengan menggunakan metode semiotika John Fiske. Hasil penelitian ini menunjukkan bahwa karakter Afrika Amerika dalam film Ghostbusters (2016) masih digambarkan berada di bawah kelas sosial orang kulit putih baik secara ekonomi dan kecerdasan. Tidak hanya itu, film Ghostbusters (2016) menggunakan karakteristik stereotip orang Afrika Amerika sebagai bahan komedi. Terakhir, peran Afrika Amerika dalam film Ghostbusters (2016) hanya sebagai kaki tangan kulit putih.
\end{abstract}

Kata kunci: Representasi, Afrika Amerika, film, semiotika, film Ghostbusters 2016.

\section{INTRODUCTION}

America is a multiethnic society. One of the ethnic living in America is the African American tribe. Racism towards African American tribe has been issues for centuries. Some fatal shootings incidents in 2016 by white cops towards unarmed black man amplify the tension between black people and white people. Not only towards civilians, racism also occurred towards public figure.

Leslie Jones is an African American actress. She received racist tweets, until she left her Twitter account. She also had a problem in looking for designer for Ghostbusters (2016) premiere. More over her personal website had been hacked, revealed her personal photos, driver's license, passport, and even compared her to a gorilla. She got all that racist treatment after she played a role in Ghostbusters (2016). In the movie, she is the only African American character out of the four main character.
She is described as the only non-scientist member in Ghostbusters.

This black character also existed in the original (1984) and second Ghostbusters (1989) movie. The black character in the first (1984) and second (1989) Ghostbusters movies was not a scientist and had to apply to be one of the Ghostbusters. In 2014 Ernie Hudson, the African American actor that played as Winston Zedemore, the black character in the first (1984) and second (1989) Ghostbusters, revealed that the first and second Ghostbusters were the most difficult part in his career. The first Ghostbusters (1984) crew cut him out of publicity posters and cut his screen time. After that he did not get a role for almost three years (Desborough, 2014)

The phenomena of how African American being represented in movie is also became a topic chosen by some scholars. One of them is Abigail Horne, an assistant professor, who teach about African 
American Literature and American Film in Hampden Sydney College, published a journal titled "The Color of Manhood: Reconsidering Pompey in John Fords The Man Who Shot Liberty Valance." Inside the journal she argue against opinions of prominent directors about a portrayal of African American character in The Man Who Shot Liberty Valance (1962) film. In the film there are two main white characters, Tom Doniphon and Ransom Stoddard, as well as one African American character named Pompey. Martin Scorsese, the director of the famous The Wolf of Wall Street (2013) only focus on the two characters in his statement about the movie, leaving the African American actor behind. Other directors also mention the character Pompey described only as a slave to the white people in that movie. Abigail Horne opposed their statement about the portrayal of Pompey in that movie. She stated that even though Pompey is not the main character of the movie but he also has the same ability as the white people in that movie, instead she argue that he is also the hero in that movie (Horne, 2012, pp. 5-24).

Therefore, through the description above, the purpose of this research is to discover how is the representation of African American in Ghostbusters (2016) movie. This study is a qualitative that focuses only on how the movie represents the African American using the semiotic analysis method. The subject of the study is the Ghostbusters (2016) movie and the object of the study is the representation about the African American that will focus only on Patty Tollan as an African American character that is one of the four lead characters in the Ghostbusters (2016) movie. While the other African American actors and actresses were only played supportive role.

\section{LITERATURE REVIEW}

\subsection{African American in Movies}

The 200 years of slavery were a period in which the subordination of blacks to whites was legitimized in the American South and informally recognized in the American Northern states. This long period of slave system create an ingrained racist ideology that continued to influence the perception of blacks by whites well into the twentieth century (Marger, 1994, p. 170).

Back then, African Americans were often discriminated in the field of work and intelligence. Even in 1987, there was Jim Crow law that regulated the segregation of the use of public facilities for whites and blacks (Guido Bolaffi, 2008, pp. 268-273). This treatment then unconsciously carried away in the depiction of characters in hollywood movies.

In the beginning of 1980s, the opportunity for black people playing in front of or behind the screen became a "remedy" to them after many of subordinations and inequalities they had struggled so hard to eradicate during the years of the civil rights movement and the emergence of the Black Power consciousness that followed it. As time went by, in most of Hollywood films, black people's behaviors were portrayed as characters that were uncivilized and thoughtless in their actions. When black people wanted to fight for something, they tended to be hesitant and not confident in coping with the problems alone. They were portrayed to have lower intelligence than whites and tended to rely on emotion and sensuality instead of intelligence or logic.

In addition, in 1980s blacks often appear on screen in the biracial "buddy formula". This means when black people appeared in a movie there is always white person playing their buddy. This strategy was to control the black filmic image and conform it to white expectations. This formula then pushed blacks into the background and made them "loyal sidekick" which indirectly subordinated them (Guerrero, 1993, pp. 113 - 127).

Donald Bogle, as in Stuart Hall's "Representation", identifies the five main stereotypes of black people (Hall, 2013, p. 239) Toms, the good negroes; Coons, the comical black character; The Tragic Mulatto, the mixed race woman; Mammies, the prototypical house servants; Finally, the bad black character.

\subsection{Semiotics}

Semiotics or semiology (that is what they call semiotics in Europe) is the science of study of signs (Brian Longhurst, 2008, p. 17). According to Rose, semiotics is an effective approach to interpret the material of visual culture (Rose, 2012, p. 105). The easiest way to determine sign is to consider the components or parts that make it up. There are two components to build sign. The first component "signifier" is sign which includes what is spoken, written, or visual symbol (such as a word, a street sign or advertisement). While the second component "signified" is the concept or certain idea that is associated with the symbol (Brian Longhurst, 2008, page 29.). For example, the word clock refers to objects that provide information about the time. The 
word clock is the signifier while the object that provides information about time is the signified.

Charles Sanders Pierce, states that sign is formed through the triangular relationship between the signs, the users and the external reality as the required models to assess meanings. This external reality is called object. Signs are both social context and culture that used to be a reference to how the object is interpreted. Meanwhile the interpretant or user is the one who gives meaning to the object, based on his/her reference and his/ her field of experience and frame of reference (Fiske, 2004, p.62). This concept was explained further in a simple model below (Chart 1).

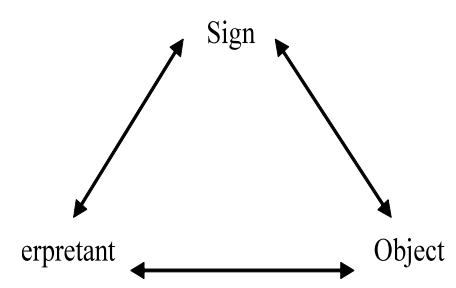

Chart 1. Pierce's element of meaning Source: Fiske (2004, p.63)

Pierce also suggests three kinds of signs that are differentiated by the way in which the relation between the signifier and signified is understood (Rose, 2012, p. 119); the first one is icon, the signifier represents the signified by apparently having a likeness to it; the second one is index, the signified and signifier has an inherent relationship; and the last is symbol that have a conventionalized but clearly arbitrary relation between signifier and signified.

The other person who talked about semiotics is Roland Barthes. According to Barthes a sign that describes something is called denotive which consist of signifier and signified. Furthermore he said that signs can also be connotive. A connotive sign can be translated into a higher level variety of meanings. This is the first order of Barthes semiological system. The second order semiological system in Barthes semiotic method is mythology. Mythology itself cannot be defined literally by the object of its message, but it has to be seen by the way in which it utters message (Rose, 2012, pp. 120-121, 131).

\subsection{John Fiske's Code of Television}

This research used semiotics method by John Fiske. Fiske uses three levels to identify a sign. In explaining the tools he uses some examples by dividing characters in a movie using "the villain" and "the hero". The first level is "reality", included in it is appearance, dress, make-up, environment behavior, gesture, expression, dialogue and tone. This first level is encoded by the social codes, that later on electronically encoded by technical codes. Therefore the second level called as "representation" includes camera work, lighting, editing, music and sound. The second level above transmits the conventional representational codes, which shape the representations of narrative, conflict, character, action, dialogue, setting, casting, etc.

The third level is "ideology" which is organized into coherence and social acceptability by the ideological codes, such as: individualism, patriarchy, race, class, materialism, capitalism, etc (Fiske, 1987, pp. 5 -11). George Gebner found that a character who is white, male, middle class (or classless) and in the prime of life is likely to be alive at the end of the program. Meanwhile characters which deviated from these norms are likely to be killed during the program in proportion to the extent of their deviance. From what has been said above we can theorize that the character who often become heroes, have social codes that embody the ideology of dominant culture. While social codes owned by characters who become criminals refer to the culture of deviance and raise contrary ideology to the heroes' ideology. The researcher will use Fiske's Codes of Television to identify social codes in the Ghostbusters (2016) movie. The social codes then display ideology about African American race in the Ghostbusters (2016) movie.

\section{METHODOLOGY}

\subsection{Research Conceptual}

As stated before this qualitative research will use John Fiske's semiotics method. The goal of this study is to discover the representation of African American in Ghostbusters (2016) movie. Representation itself is a way mass media portrays world. However, what is represented in mass media cannot represent the real world as a whole. Therefore media will only represent a part of the world according to the media's perspective and chosen angle (Brian Longhurst, 2008, p. 50). In other words, representation is how sign, "things", and concept are linked together to generate meaning. Therefore this study will describe more about the meaning of the signs that linked together in the movie referred to African American ethnicity based on the maker's culture. 


\subsubsection{Research Target}

The subject of this research is the third Ghostbusters (2016), released July 22, 2016. This movie was reproduced by Sony Pictures Entertainment with Ivan Reitman as the producer. As what the researcher has stated in the introductions the researcher will only focus on the African-American character in the movie. Meanwhile the object of this research is to determine the representation of African-American in the Ghostbusters (2016).

\subsubsection{Analysis Technique and Data Interpretation}

The data analysis technique that the researcher will use is John Fiske's Codes of Television. The researcher will select some footage from the Ghostbusters (2016) that represents African Americans by sorting each sign into three types: reality, representation, ideology. The first analysis stage is defining the object of research analysis which is described by the signs in the movie that are African American representations in the Ghostbusters (2016) movie. Then the researcher gathers the text in the form of a collection capture of a specific scene that is considered relevant in representing African American. After that, the researcher will describe the contents of the texts or images carefully by identifying all of the elements of the image and deciphering it into the three levels of John Fiske's Codes of Television: reality, representation, and ideology. After sorting by the three levels of John Fiske's Codes of Television that are contained in the text, the data findings will be analyzed and studied in theory to supplement the data findings so that the findings will not deviate from the background of the problems. For the interpretation of the data, the researcher will present the findings with existing theories that later on can be seen whether the findings are in sync or not with existing theories. Last, the researcher then draw conclusions about the form of the representation of African Americans in Ghostbusters (2016). This last stage is to answer the problem statement that has been stated previously, which is to determine how African Americans are represented in the film Ghostbusters (2016) (Stokes, 2003, pp. 74 - 75).

\section{DATA FINDINGS}

There are four main character in Ghostbusters, Erin Gilbert, Abby Yates, Jillian Holtzman, and Patty Tollan. As stated before this research will examine how the representation of Patty Tollan as African American character in Ghostbusters. In the sections below the researcher will analyze the signs contained in the movie according to level one and two of John Fiske's semiotic method, reality and representation, which then reinforced with the data about the maker's culture and socio economic circumstances in real life, in America.

\subsection{Patty's job difference with the other three members}

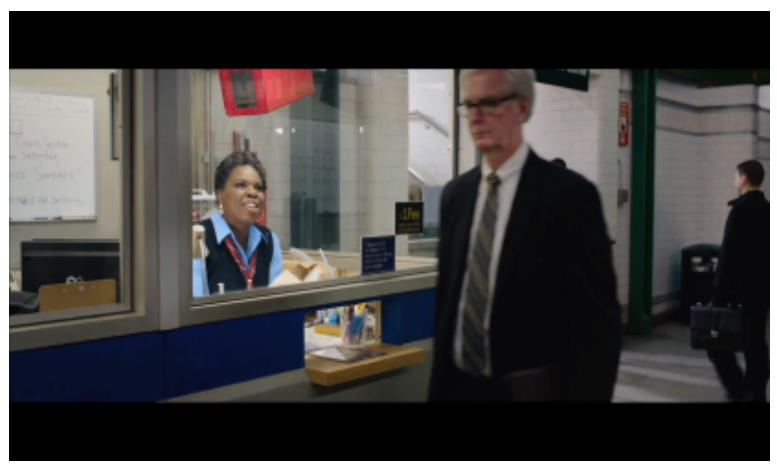

Picture 1. Patty at her work place

Unlike the other three members, Patty Tolan was introduced as a mere subway worker. Even though she greeted every person who passed by with big smile, but they ignored her. She was even ignored by black people who had the same color skin as her. This fact even got clearer when Rowan said that she was ignored because she was a laborer.

"They will always ignore you. When the Fourth Cataclysm begins, laborers, such as yourself, will be among the last led to the butchery."

She would be the last to be killed because she did not matter that much. She was alienated in her workplace. There is also a scene that shows Patty's workplace as an unsanitary place. Patty's workplace was the worst compared to the other three members. It was filthy and she was being alienated. Meanwhile, the other members who work as scientists could pursue their passion by working their job in great universities. Patty herself had ever complained about her work. She said that being an MTA worker was not perfect but at least it was better than being a Ghostbusters who always dealt with ghost. This also meant that she did not fit in the Ghostbusters and easily gave up with that situation.

Patty described preference as an MTA worker rather than as a Ghostbusters member meant that she preferred working in public sector than in private sector. According to Jennifer Laird, a sociologist at University of Washington who had been researching 
about black people who worked in public sector, in The New York Times, black people preferred working in the public sector rather than in the private sector because it had a better payments, stability, a more professional and managerial opportunities. In other words, most of them worked in public sectors to avoid any discrimination in private sector. The percentage of black women who worked in public sector is $21,4 \%$, the highest compared to black men, white men and women. Furthermore, it was easier to work in a public sector because they could work in public sector even without a college degree. Thus, a lot of African Americans considered working for the government (in public section) as their pathway to be in middle class even without college degree (Cohen, 2015).

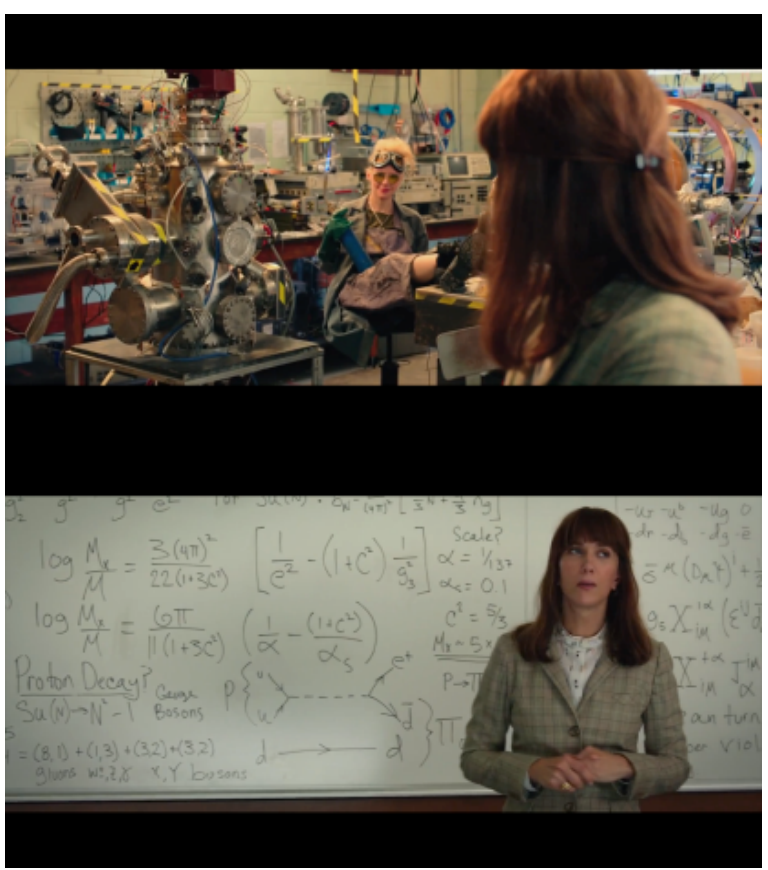

Picture 2. Other three members at their work place as scientists

As for the salary, in 2013, the American Association of University Professors' annual report placed Columbia University as the best paying college in the country with average full professors salary as much as $\$ 212,300$ a year (Kingkade, 2013). In 2014, according to payroll data released by the Empire Center Thursday, one in four Metropolitan Transportation Authority employees made $\$ 100.000$ a year (Prendergast, 2015).

With a lower wage than Erin, Patty's job did not seem requiring any high education or skill as her background since all she did were only sitting, checking the CCTV, seeing whether there was something strange or not, answering if somebody needed a help with their tickets, and maintaining station's cleanness. This proved that Paul Feig as Ghostbusters (2016)' director still fixated in the stereotype that black people always worked in unskilled and public sector areas.

\subsection{Intelligence difference between Patty and the other three members}

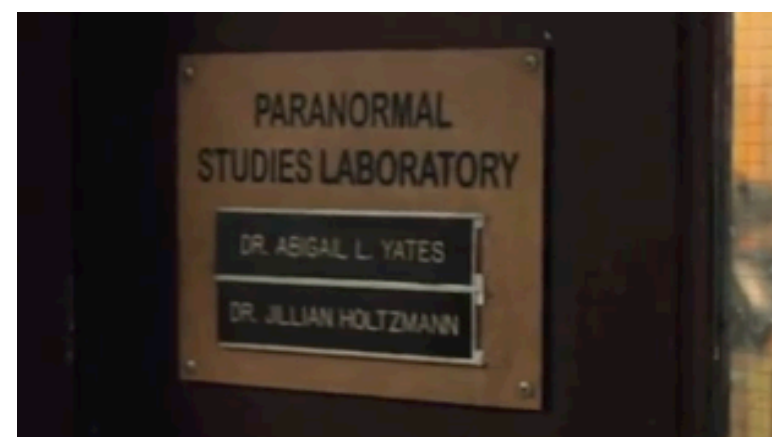

Picture 3. Abby and Holtzman's names on Paranormal Studies Laboratory's door

Patty's knowledge as a subway worker was only about the building's history which was not a main requirement of a subway worker. Patty's educational background remained unknown until the end of the movie whereas the other members were scientists. Erin was a lecturer in a big university and Abby and Holtzman had a Doctor title in their names, the three of them surely had a high education background.

There were several times when Patty did not understand what the other three members said in scientific discussion. In the scene when the Ghostbusters investigated the subway station, Abby asked a teenager about ghost sighting with scientific terms. When Patty heard that term she flinched then asked Abby,

"Can you speak in English?"

Her confused expression was clear in a medium close up shot. English was American's main language. Abby's scientific language sounded like a foreign language to Patty. It meant that scientific language was all Greek to Patty. Every time the three members discussed about a way to defeat the ghost scientificcally, she always remained silent or asked about some terms. This confused expression was also being framed in a medium shot to show her expression clearly.

The same thing also happened in the final battle. This time, the director put the white scientists in one frame when they were discussing on how to take down the 
giant Rowan ghost, leaving Patty alone in a medium shot when she panicked, was confused, but remained silent and let the other three members discuss on the plan. Those two shots were next to each other, therefore it eventually made the gap of intelligence between Patty and the other three members even clearer.

However, on the climax of the battle, when the scientists' plan did not work, Patty suggested an idea to close down the ghost portal and the other scientists agreed with it. Abby even said that Patty's genius with that idea. After joining the Ghostbusters, Patty finally gave an idea that was accepted by the other members. This was like a medicine for the all of the scenes that showed Patty's lack of intelligence.

\subsection{Patty's behavior compared to other three members}

Patty's behavior when she saw a ghost was different from the other members. While the other members considered a ghost as their research specimen, Patty thought that a ghost was a scary thing. In this movie there are several scenes that show Patty cowardice after seeing a ghost. Out of the Ghostbusters member, the director chose Patty unconsciously showed the stereotype of African American as a coward.

The image of a timid black man can also be found on the previous Ghostbusters (1989). On that scene Winston, Ray, and Egon were investigating an unused subway track in order to know the source of the evil slime. Suddenly, there was a train Ghost passed them. Ray and Egon managed to get out of the railway. On the other hand, Winston was standing still and screaming while the train ghost passed through him because he was too scared.

In one scene when Patty brought her uncle's car, Erin jokingly asked Patty,

"Hope you checked to see there wasn't a body in the back (smirk)"

This kind of joke proves that Erin slightly imagine of Patty's stupidity. Patty's answer that she really did not check the car surprised the other three members and showed how careless she was. It also proved their assumption on Patty's silliness.

In addition, the fact that Patty left her stable payment job and chose to be a member of a paranormal scientist without any consideration itself also proves her recklessness.

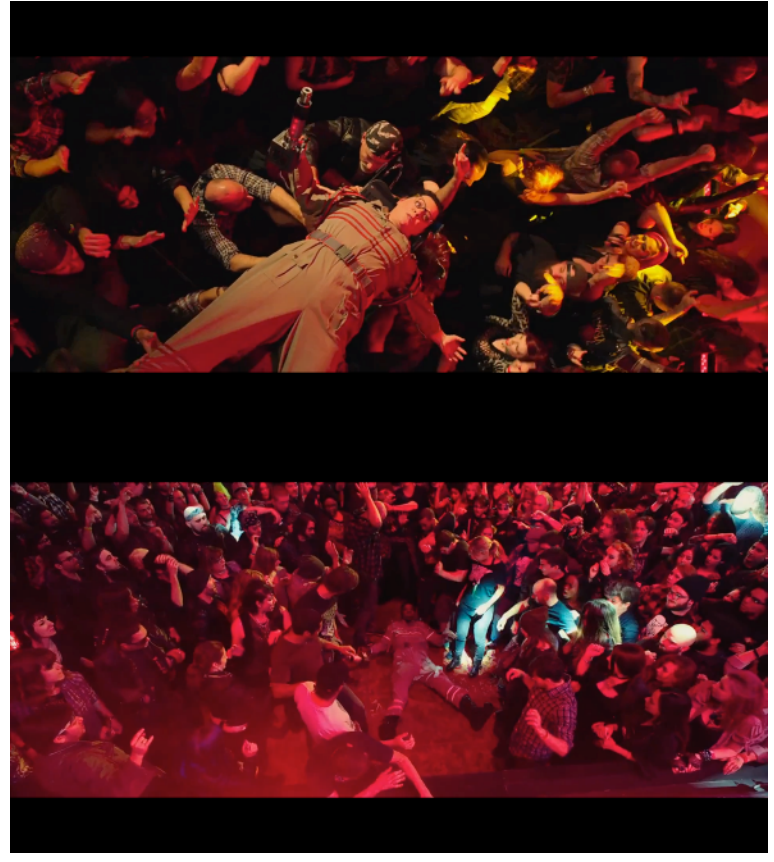

Picture 4. The crowd want to carry Abby but not Patty

Moreover, Patty is also described as a rude or illmannered person. In several scenes Holtzman and other character said Patty is mouthy and ungraceful. Being loud, arrogant, rude, and so on that are considered as misbehavior by white people are a stereotypical of black people (SchnellerJr., 2008, p. 289). The screen capture above, is the scene that shows the difference of Patty and Abby behavior in asking a favor. Patty described as a rude person when she asked the crowd to move. Patty and Abby has the same big appearance, the difference are their way to ask a favor and their race, the crowd shows racist reaction because they want to carry Abby instead of Patty.

On other several scenes Patty described as a loud character because she tend to scream when she speak. Not only that the way Patty speak, including her intonation and repetition in some words are part of African American way of speak. This Negritude then used as an anti-racism movement in attempt to be equally accepted based on characteristic difference with the other race (Guido Bolaffi, 2008, pp. 6-7).

Being deprecated, less intelligence, discriminated, cowards, rude, and black in media are a way of shaping black characters according to white's expectations. The deployment of these black characters in comedic movies shows that media intents to make black character as laughing stock. In addition, black characters in movies often have a less exclusive role 
than white character. All the attention towards media given by the audience, unconsciously supports media's role in creating and reinforcing prejudice towards minority group. It cannot be denied that media has the ability to provide constructions of issues and events about which most of the audience, whom mostly white people, may have little direct knowledge (Guido Bolaffi, 2008, pp. 252-255).

\subsection{Fashion difference between Patty and the other three members}

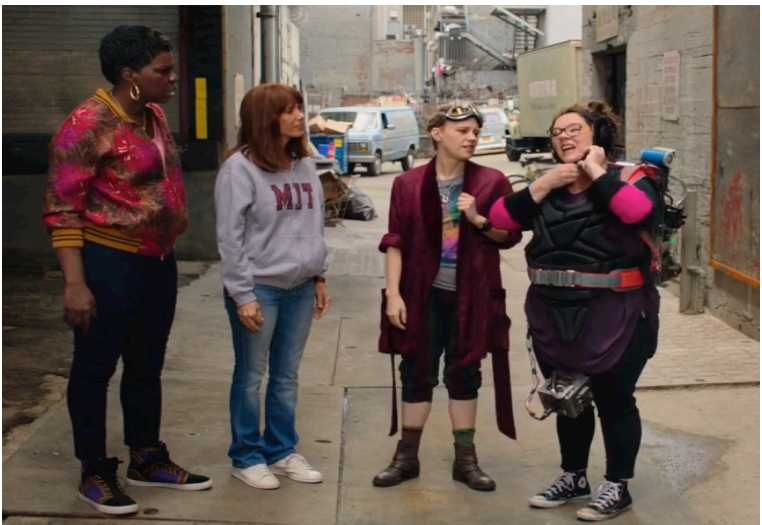

Picture 5. Patty's clothing difference from the other members' clothes.

Fashion is an object that can illustrate how crucial tensions in society. Fashion is a result from upper social classes' need to distinguish themselves from lower social classes (Godart, 2012, p. 24). That is why through fashion people can tell someone's culture and class, so does Patty's fashion compared to the other members.

Patty's dress codes were always different from the other members. She dressed mainly in pink with gold accessories especially round gold earrings, and she often wore sneakers, also a sporty watch. Her hair was "torsion twisted", sometimes some of which was colored in red sometimes in blue or both, or even in brown. The style is identical with Missy Elliott, one of famous rappers in 90 s era. She wore jacket, sneakers and gold accessories too like the picture below (Picture 5).

The gold accessories Patty wore were part of hip-hop fashion called "bling-bling". This kind of hip-hop fashion with "bling-bling" is also called as Ghetto fabulous. Ghetto fabulous is a fashion that is originated from African American who lived in ghetto area in inner city. According to Oxford: Advanced Learner's dictionary, Ghetto itself is the area of town mainly lived in by particular national or social group. Ghettos are usually crowded with poor housing conditions. This kind of condition also called as black urban ghettos. The mainstream stereotype of people who wear this kind of fashion is they seem to have a wealthy life style when in fact they are not. They want to show that they are success through brands and golds (Tribune, 1999).

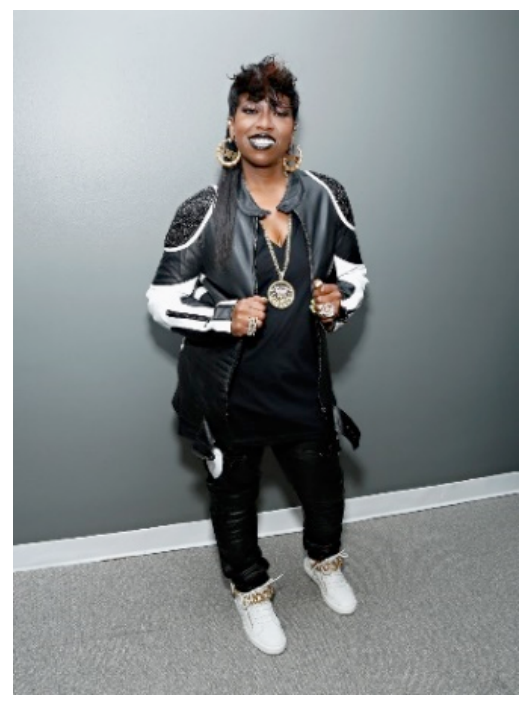

Picture 6. Missy Elliott fashion

Source: https://lockerdome.com/6614054181553473/6836902486736916

\subsection{Patty's relationship with other three members}

As the only member who did not know much about science, Patty tried her best to help out the other three members. In the screen shot below show Patty's contribution for the team by making their costumes. Not only that, Patty also took care of Ghostbusters meal

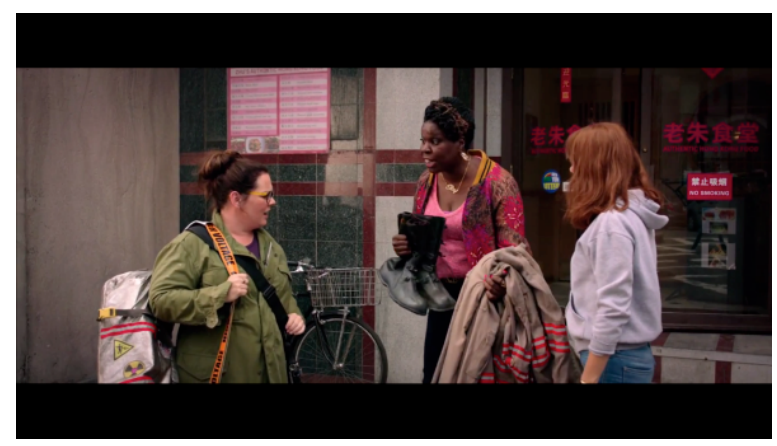

Picture 7. Patty made clothes for the members

The other example of Patty helpfulness is when Patty brought her uncle's car for Ghostbusters. However the members looked disappointed because the car was a 
hearse. Then Patty responded their disappointment by saying:

"I'm sorry. My uncle owns a funeral home not an Enterprise Rent-A-Car."

This means Patty and the other three members all knew that it would be more dashing if the car was from the Enterprise Rent a Car than from a funeral home. Enterprise rent a car is a big rent a car service not only in United State but also in over 30 countries with more than 7,200 locations. Founded by a white American, Jack C. Taylor, Enterprise rent a car offers complete transportations such as: cars, truck, and motorcycle (Enterprise Holdings, n.d.). Being an owner of this business must be very rich compared to funeral home owner. This means that she confesses that she is not rich.

The statement showed how Patty took care of the scientists' nutrition intake. During the slavery period there is a dominant image of black women as a slave. They called the black women as "mammy". This mammy does not mean as mother literary. They called her mammy because of her affection to white children, woman and man. She gives advice, love, correction, doting, and supervision to white children and woman. She is taking care of them, like babysitting them. She is strong, supportive, and nurturing (Banes, 2014, pp. 85-87)

Patty's big and strong appearance also support her role as the team's mammy. There are a lot of African American actress with various physical characteristic, yet the director chose Patty with her big appearance. Through the scene when Abby was possessed by Rowan ghost, Patty was stronger to fight Abby with big body and the ghost power than Holtzman who has smaller physical build. One of mammy's characterristic is an overweight since her image as a caregiver (Banes, 2014, p. 85).

This kind of image is similar with other black woman character in other movie as a mammy. The left screen capture above is the screen capture of the black character in Gone with the Wind (1939), mammy was described as black person who served a noble from her dish to her dress. While the right screen capture is the archetypal of black woman in Malibu Most Wanted (2003), the mammy also served the white rich male's lunch. Patty's archetype of mammy is a modernized type of mammy. She did not do it as literary a slave of white people. Even though the slavement period has ended, Patty's behavior was still influenced by the way black women used to be.

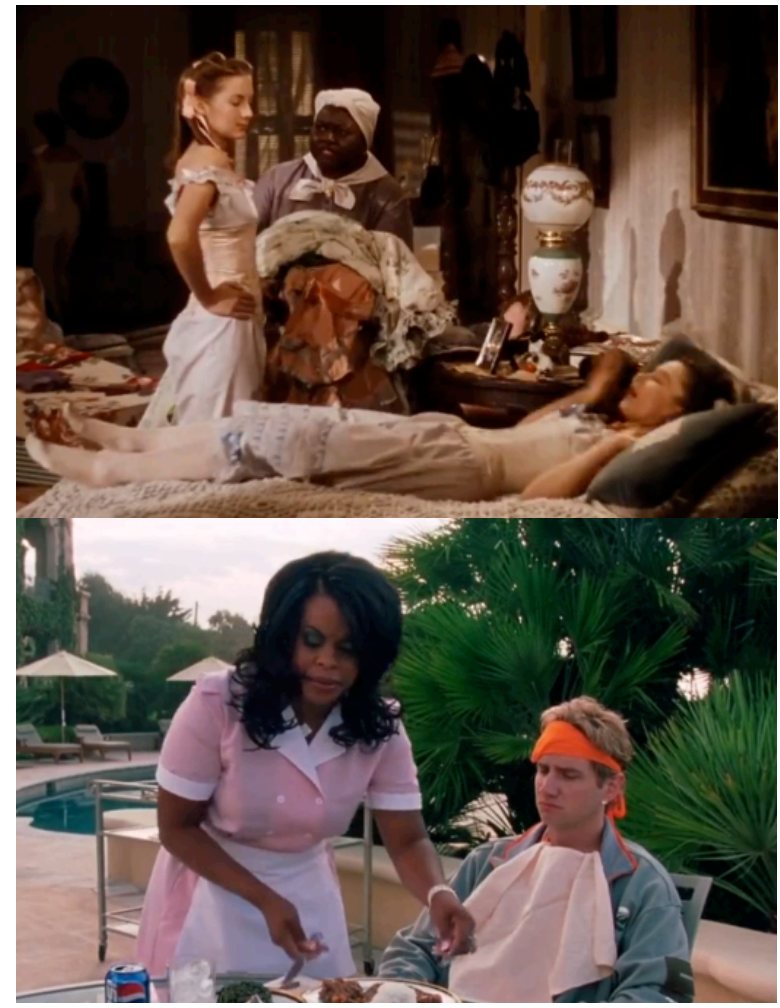

Picture 8. Mammy's archetypal: serving their white master by preparing their dresses and meals.

From left, source: screenshot from Gone with The Wind (1939) and Malibu Most Wanted (2003)

Despite of what Patty had done to help the Ghostbusters members, still there were times when she was segregated. There are some scenes related to this statement. The first one was after they were trying a new weapon that Holtzman had built. The Ghostbusters was eating two box of Papa John's pizza. Erin and Hotlzman hold the same pattern disposable cup considering it was from Papa John's pizza, while Abby was holding a mug. Patty only drink from a red disposable cup, solo cup, which is used for parties and occasional events. It means that the members still did not fully accept Patty as part of Ghostbusters. On the other scene, even though Patty tried her best but in the battle field her combat skill described not as good as the other three members.

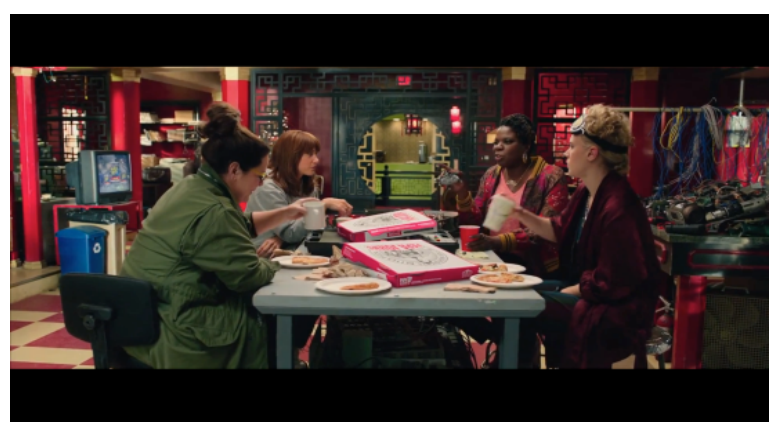



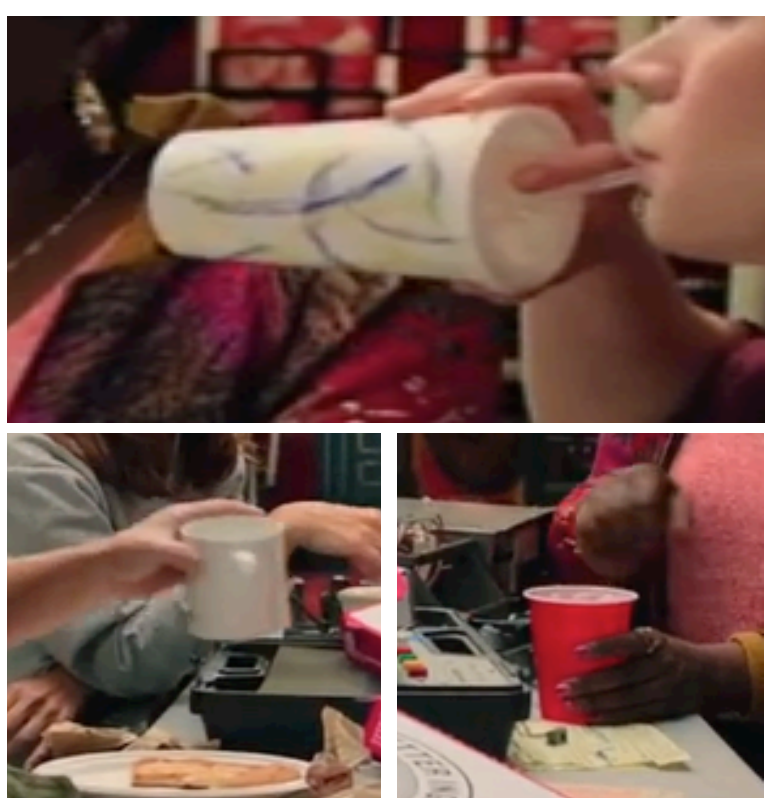

Picture 9. When Patty and the other three members were eating

\section{INTERPRETATION AND DATA ANALYSIS}

In this section the researcher will analyze deeper by looking for the bigger picture of the relationship of the signs that have been found above, as well as the third level of John Fiske's code of television, ideology. Through John Fikse's semiotic method, the researchers obtained an overview of African American character portrayal in Ghostbusters (2016) movie. African American character in this movie is still represented as a figure which is in the lower social level compared with the white. Hence we knew that the ideology adopted in the movie is subordination of black people.

This ideology is shown from the depiction of the African American character who has lower economic status than the whites. Patty's fashion also Patty's job as a subway worker has a lower wages than Erin as a lecturer in a big university. Patty herself accepts the imposed stereotype as a person in lower economic rank. This is shown from her statement that compare her uncle business with Jack C Tyler's, as the owner of Enterprise Rent a Car.

The African American character in this movie also represented in a lower intelligence level than whites. Patty's educational background in the movie was remained unknown while the other three scientists were all have a Doctor title in their name. She always did not understand the other three members' scientific terms. African American job role which have been imprinted as "common" is a job that serves white people. In Ghostbusters, Patty serves Erin, Abby, and Holtzman, by providing their transport, costumes and food. Those are task that did not need a high education. The job difference between whites and blacks raises the gap between them. The first time Patty said she wanted to join Ghostbusters, Erin seems unwilling to let Patty join the team because of her background as a non-scientist.

The Ghostbusters (2016)' African American character is still created in accordance with the thought of the African American stereotypical figure developed in society. The African American character is described as a rude, coward, reckless, also loud person. This characteristic is then used as a laughing stock in this comedic movie. Through the jokes and humor, the prejudices against blacks are reshaped and further reinforced by the depiction of African American stereotypes in this movie.

The African American role in this movie was created not as grand as the role played by white figures. Although the African American character in this movie was told as a part of the hero team, but result from the analysis above the role played by African American in this film was only as a side role compared to white character. African American in this movie played the role of white good friends and loyal sidekicks. Hence the real hero role in this movie is indirectly played by the whites.

\section{CONCLUSION}

Overall, the representation of African American in Ghostbusters (2016) is still referred to African American stereotypes live in society. Although the creator of the movie attempts to elevate the role of African American by including the character as part of the hero, the African American character in this movie is still portrayed subordinated from the white race. Through John Fiske's Code of Television, the signs in this movie shows that the African American character is represented as being less intelligent, less economic status, rude, reckless, coward, and as servant. Those characteristics then packed in a comedy that ultimately reinforces the belief in the stereotype of African American people in society. Thus, this movie unconsciously show a subordinated African American character in it. 


\section{REFERENCES}

Banes, C. W. (2014). Too Heavy A Yoke: Black Women and the Burden of Stregth. Eugine: Cascade Book.

Brian Longhurst, G. S. (2008). Introducing Cultural Studies. Gosport: Pearson Education Limited.

Cohen, P. (2015, May 24). Public-Sector Jobs Vanish, Hitting Blacks Hard. Retrieved May 13, 2017, from The New York Times: https://www.nytimes.com/2015/05/25/business/ public-sector-jobs-vanish-and-blacks-takeblow.html

Desborough, J. (2014, August 29). EXCLUSIVE: What Happened to Ernie Hudson? Forgotten Fourth Ghostbusters Reveals Franchise was 'Most Painful' Part of His Career... But He'd Love to Make Another. Retrieved March 20, 2017 from dailymail: http://www.dailymail. co.uk/ tvshowbiz/article-2738009/Ernie-Hudsonreveals-Ghostbusters-painful-career.html

Enterprise Holdings. (n.d.). About Us. Retrieved from Enterprise: https://www. enterprise.com/en/ about.html?icid=footer.company-aboutENUS.NULL

Fiske, J. (1987). Television Culture: Popular Pleasures and Politics. Great Britain: TJ International Ltd.

Fiske, John. (2004). Cultural and Communication Studies. Yogyakarta: Jalasutra

Horne, A. (2012). The Color of Manhood: Reconsidering Pompey in John Ford's The Man Who Shot Liberty Valance. Black Camera, 4-27.

Kingkade, T. (2013, August 19). The 10 Colleges That Pay Professors The Most According to
AAUP's 2013 Survey. Retrieved May 03, 2017, from huffingtonpost: http://www.huffingtonpost.com/2013/08/19/colleges-pay-professorsmost-2013-aaup_n_3781207.html

Godart, F. (2012). Unveiling Fashion: Business, Culture, and Identity in the Most Glamorous Industry. New York: Palgrave Macmillan.

Guerrero, E. (1993). Framing Blackness. Philadelphia: Temple University.

Guido Bolaffi, R. B. (2008). Dictionary of Race, Ethnicity \& Culture. Callifornia: SAGE Publications Inc

Marger, M. (1994). Race and Ethnic Relations: American and Global Perspective. Belmont, CA: Wadsworth Publicing Company.

Hall, S. (2013). Representation. Great Britain: Sage.

Prendergast, D. (2015, July 16). 25 percent of MTA workers earned six-figure salaries last year. Retrieved May 03, 2017, from New York Post: http://nypost.com/2015/07/16/heres-why-yoursubway-fare-keeps-going-up/

Rose, G. (2012). Visual Methodologies. Gosport: SAGE Publications.

SchnellerJr., R. J. (2008). Blue \& Gold and Black: Racial Integration of the U.S. Naval Academy. Texas: Texas A\&M University Press.

Stokes, J. (2003). How to Do Media \& Cultural Studies. Great Britain: SAGE Publications Ltd.

Tribune, R. G. (1999, October 9). Rapper Attitude in Designer Diamonds and Furs: Ghetto Fabulous Goes Global. Retrieved May 03, 2017, from The New York Times: http://www. nytimes.com/1999/10/09/news/rapper-attitudein-designer-diamonds-and-furs-ghetto-fabulous-goes.html 